\title{
Online data collection strategies used in qualitative research of the health field: a scoping review
}

\author{
Estratégias de coleta de dados online nas pesquisas \\ qualitativas da área da saúde: scoping review \\ Estrategias de colección de datos online en la investigación \\ cualitativa del área de salud: revisión de escopo

\section{Pétala Tuani Candido de Oliveira Salvador ${ }^{a}$ Kisna Yasmin Andrade Alves ${ }^{\mathrm{a}}$ Cláudia Cristiane Filgueira Martins Rodrigues ${ }^{a}$ Lannuzya Veríssimo e Oliveira ${ }^{a}$}

How to cite this article: Salvador PTCO, Alves KYA, Rodrigues CCFL, Oliveira LV. Online data collection strategies used in qualitative research of the health field: a scoping review. Rev Gaúcha Enferm. 2020;41:e20190297. doi: https://doi.org/10.1590/19831447.2020.20190297
- Universidade Federal do Rio Grande do Norte (UFRN) Nursing school. Natal, Rio Grande do Norte, Brazil.

\section{ABSTRACT}

Objective: To identify and map the online data collection strategies used in qualitative researches in the health field. Methods: This is a scoping review guided by the Preferred Reporting Items for Systematic reviews and Meta-Analyses extension for Scoping Reviews (PRISMA-SCR) from the Joanna Briggs Institute. We analyzed scientific articles, theses and dissertations from 12 databases. The analysis was made by descriptive statistics.

Results: The final sample consisted of 121 researches. It was found that the number of publications increased sharply in the last five years, with predominance of studies from the United Kingdom. The highlight fields were psychology (28.1\%), medicine (25.6\%) and nursing (12.4\%). The publications used 10 online data collection strategies: Online questionnaires, online forums, Facebook, websites, blogs, e-mail, online focus group, Twitter, chats, and YouTube.

Conclusions: Online data collection strategies are constantly expanding and increasingly used in the health area.

Keywords: Qualitative research. Health sciences. Internet. Internet access. Online social networking. Social media.

\section{RESUMO}

Objetivo: Identificar e mapear as estratégias de coleta de dados online utilizadas nas pesquisas qualitativas da área da saúde.

Métodos: Trata-se de scoping review norteada pelos pressupostos do Joanna Briggs Institute segundo Preferred Reporting Items for Systematic reviews and Meta-Analyses extension for Scoping Reviews (PRISMA-SCR). Foram analisados artigos, teses e dissertações, identificados a partir de 12 bases de dados. A análise se deu por estatística descritiva simples.

Resultados: A amostra final constituiu-se de 121 pesquisas. Verificou-se que as publicações acentuaram-se nos últimos cinco anos, com predominância de estudos do Reino Unido, as áreas de destaques foram psicologia (28,1\%), medicina (25,6\%) e enfermagem $(12,4 \%)$. Foram utilizadas 10 estratégias de coleta de dados online: questionário online, fórum online, facebook, sites, blogs, e-mail, grupo focal online, twitter, chats e youtube.

Conclusões: Pode-se afirmar que as estratégias de coleta de dados online estão em constante expansão e utilização na área da saúde. Palavras-chave: Pesquisa qualitativa. Ciências da saúde. Internet. Acesso à internet. Redes sociais online. Mídias sociais.

\section{RESUMEN}

Objetivo: Identificar y mapear las estrategias de colección de datos online utilizadas en la investigación cualitativa del área de la salud.

Métodos: Esta es una revisión de escopo guiada por los supuestos del Joanna Briggs Institute de acuerdo con Preferred Reporting Items for Systematic reviews and Meta-Analyses extension for Scoping Reviews (PRISMA-SCR). Analizamos artículos científicos, tesis y disertaciones, a partir de 12 bases de datos. El análisis se realizó mediante estadística descriptiva.

Resultados: La muestra final consistió en 121 investigaciones. Se encontró que las publicaciones se acentuaron en los últimos cinco años, con predominio de estudios del Reino Unido, las áreas más destacadas fueron la psicología $(28,1 \%)$, la medicina $(25,6 \%)$ y enfermería (12,4\%). Fueran utilizados 10 estrategias de colección de datos online: cuestionario en línea, foro en línea, Facebook, sitios web, blogs, correo electrónico, grupo focal en línea, Twitter, chats y YouTube.

Conclusiones: Se puede afirmar que las estrategias de colección de datos online se están expandiendo constantemente en el área de la salud.

Palabras clave: Investigación cualitativa. Ciencias de la salud. Internet. Acceso a internet. Redes sociales en línea. Medios de comunicación sociales. 


\section{口INTRODUCTION}

The qualitative methodology has been widely used in studies in the health field, since it is capable of incorporating meanings and intentions as things inherent to the acts, relationships and social structures of the subjects being studied. As such, it makes a detailed analysis of human constructs and relationships possible ${ }^{(1)}$.

Therefore, the researcher who uses a qualitative method seeks a more detailed understanding of the subjectivity of the subject, as well as of the theme being studied, considering their context.

With the advance of knowledge, the surfacing of information and communication technologies (ICTs) and the increased ease of access to digital resources, the use of online media and computer-mediated communication has been increasingly common in researches. The internet is a great example of this, transforming types of behavior and communication, and, due to how easy to use it is, it becomes a resource in the collection of qualitative data ${ }^{(2)}$.

After all, through the Internet, it is possible to carry out indepth studies about virtual space relationships, the interface of people's daily lives. Therefore, it can generate new types of knowledge and data collection, in addition to exploring the daily lives of specific groups that have certain features in common ${ }^{(3)}$.

In this interface, the surfacing of virtual communities stands out, as well as that of social networks, which expanded the understanding of the communication field and use of cyberspace.

This type of communication is basically electronic and mainly based on words (texts) and/or images. That helps researches that seek to use it as a data collection strategy, as it makes possible to carry out studies about themes such as online identity and sociability.

It is also possible to collect data in online discussion forums, sites in which a certain group, with common features, gathers to debate a certain theme. That makes a dialogic approach possible, one that focus on the meaning of the field of interest being studied ${ }^{(4)}$. This type of data collection becomes even more pertinent for researches in the field of health and Nursing, since online forums and communities are increasingly used as sources of data collection. They are even used by patients and their relatives as sources of therapeutic support ${ }^{(2)}$.

Therefore, data collection reaches a new standard, in which respondents have access to the research in an online space which can be accessed whenever desired - in the case of asynchronous strategies, in which the researcher and the research subject do not need to be connected simultaneously - and more comfortably. Comfort is also a factor in synchronous strategies, even when simultaneous access is required, since the simultaneity happens online and not in the physical space, meaning the subject can be in the environment of their choosing ${ }^{(3-4)}$. Additionally, the researcher can directly monitor the progress of the research, as data is uploaded into digital platforms ${ }^{(1-2,4)}$.

Therefore, it becomes evident that the online space is, simultaneously, a new space to collect qualitative data and a necessary field of investigation if one wishes to understand how human relations happen in digital environments, especially concerning its use as a source of information about health. Therefore, this is a theme that needs to be understood by qualitative researchers. The first step to do so is understanding how each online data collection strategy has been incorporated into qualitative investigations.

Researchers have highlighted that investigations based on online data collection strategies are a reality that brings them both benefits and challenges ${ }^{(1-4)}$. However, no study was found that presented how researchers of qualitative health field investigations have been incorporating these innovations into their researches, thus showing how necessary the current investigation is.

Therefore, it becomes pertinent to map online data collection strategies that have been used in qualitative health field researches. This mapping can be the base for researchers to effectively incorporate these resources in their investigations.

As a result, this research aims at answering the following research question: what are the online data collection strategies used in qualitative researches in the health field? Therefore, this study aimed at identifying and mapping online data collection strategies used in qualitative health field researches.

\section{METHODS}

This is a scoping review - a type of literature review aimed at mapping the main concepts and limitations of a certain field of research, as well as the evidences for professional practice - guided by the prescriptions of the Reviewer's Manual(5) from the Joanna Briggs Institute (JBI) and presented according to the recommendations of the Preferred Reporting Items for Systematic reviews and Meta-Analyses extension for Scoping Reviews (PRISMA-SCR): Checklist and Explanation. Its protocol was registered at Open Science Framework. 
A research protocol was created including the items: type of study, objective, sample composition, research question formulation, inclusion criteria, exclusion criteria, data collection, data extraction and data synthesis.

The sample was made up of qualitative samples of the field of health which used digital means as data collection mechanisms.

The research formulation used the PCC mnemonic device, in which: $\mathrm{P}$ (Population) - qualitative research; C (Concept) - online data collection strategies; and C (Context) - the health field. As a result, the research question found was: "what online data collection strategies have been used in qualitative researches in the health field?".

To find scoping reviews or other protocols that are similar to those defined in the objectives of this study, a research was carried out in November 2018, in the data bases JBI, Clinical Online Network of Evidence for Care and Therapeutics (COnNECT+), Database of Abstracts of Reviews of Effects (DARE), The Cochrane Library and the International Prospective Register of Ongoing Systematic Reviews (PROSPERO). No studies were found whose objective was identifying and mapping online data collection strategies from qualitative researches in the health field.

With regards to the elaboration of a research strategy, the bases PubMed Central (PMC) and Cumulative Index to Nursing and Allied Health Literature (CINAHL) were mapped according to the main English descriptors for studies which approached the theme, found at the Medical Subject Headings (MeSH) website. To identify the descriptors in Portuguese, the Descritores em Ciências da Saúde (DeCS), from the Biblioteca Virtual em Saúde (BVS), was used.

As a result, the following research strategies were used: 1) MeSH: [("Qualitative Research" OR "Qualitative Studies") AND ("Online research" OR "Online focus groups" OR "Online interview" OR Internet OR "Online forum")], using the C (Health Sciences) as a search filter; 2) DeCS: [("Pesquisa Qualitativa" OR "Método qualitativo") AND ("Método online" OR Online OR "Grupo focal online" OR Internet OR "Entrevista online" OR "Comunidades Virtuais" OR "Pesquisa online")] - the C (Ciências da Saúde) was used as a search filter.

In December 2018, data was collected from the databases CINAHL, Web of Science, Scopus, Literatura Latino-americana e do Caribe em Ciências da Saúde (LILACS) and Electronic Theses Online Service (ERIC). Grey literature (theses and dissertations) was researched using the databases Catálogo de Teses e Dissertações da Coordenação de Aperfeiçoamento de Pessoal de Nivel Superior (CAPES), Europe E-Theses Portal
(DART), Electronic Theses Online Service (EThOS), Repositório Científico de Acesso Aberto de Portugal (RCAAP), the National ETD Portal and Theses Canada.

The research included qualitative researches, published in-full, in English, Portuguese, Spanish or French, that used online data collection strategies with subjects. The research excluded editorials, experience reports, theoretical essays, integrative reviews, and researches that used other data collection mechanisms. No temporal limit was delimited, since the objective was to trace a temporal line with regards to online data collection strategies in researches from the health field.

In the stage of study selection, at first, titles and abstracts were evaluated, to verify whether the works were suitable considering the inclusion and exclusion criteria. This was done independently by two researchers, and a third one did the same in case of conflicting opinions.

Pre-selected studies were recovered in full. It stands out that, at this point, the pool was checked for duplicates, and nine researches were excluded.

Studies were then read in full. Those that did not answer the research question were excluded, a total of 125 works. From these, 64 studies had a quantitative approach, 32 did not use online data collection strategies, 24 did not belong to the field of health (being offeredas results by the databases despite the use of filters) and 5 were not research articles (they were reflections and reviews). Therefore, 121 researches were a part of the final sample of this scoping review.

Data was tabulated using spreadsheets built in Microsoft Excel, including the following variables: type of study, year, country of origin, author's field of knowledge, type of research, data collection procedures, online data collection strategy, data analysis procedures, research subjects, benefits and limitations of the use of the online research strategy. Data was extracted and then analyzed using simple descriptive statistics ( $n$; \%).

\section{Q RESULTS}

The final sample included 121 researches, representing $0.05 \%$ of all researches found at first and $49.2 \%$ of the studies that passed the pre-selection stage and were read in full (Figure 1).

Most works in the sample were scientific articles, whose numbers increased throughout the years. Publications from the last five years stand out, as well as those carried out by Psychology, Medicine, and Nursing researchers (Table 1). 


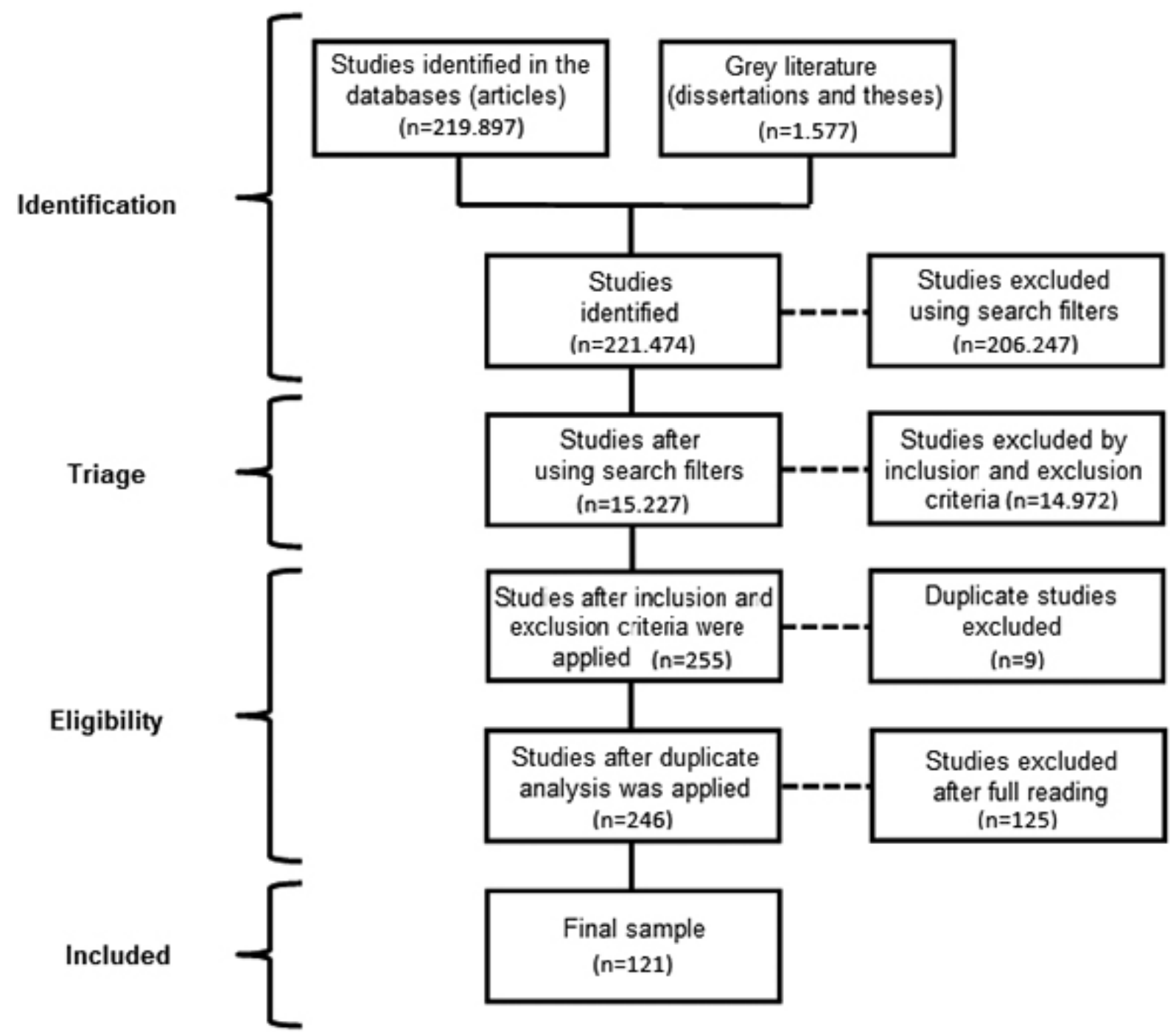

Figure 1 - PRISMA ScR flowchart (adapted) of the research study selection Source: Research Data, 2019.

The researches were carried out in 20 different countries. Most of them were carried out in the United Kingdom, the United States, Canada and Brazil (Figure 2).

Regarding the type of research described by the authors of the researches analyzed, most investigations had a qualitative approach (88.4\%), while the others claimed to have used a mixed-approach to data analysis (11.6\%).

Some investigations (22.3\%) also presented a typology for research in addition to their own typology, among which ethnographic studies stood out (9.9\%).

With regards to the data gathering procedures used, most researches exclusively used online data collection strategies (83.5\%), while the others (16.5\%) used online strategies paired with others, which were: interviews in person (10.8\%); physical focus groups (5.0\%); telephone interview (3.3\%); document analysis (1.7\%); and observation (0.8\%).

It is important to highlight that many researches used more than one data collection strategy. That includes both those whose strategies were exclusively online and those that combined other approaches, which explains the results above $100 \%$.

The online data collection strategies were: online questionnaires (27.3\%); online forums (27.3\%); Facebook (14.9\%); websites (9.9\%); blogs (9.1\%); e-mails (8.3\%); online focus groups (5.8\%); Twitter (4.1\%); chat rooms (2.5\%); and Youtube (0.8\%).

Content analysis (47.1\%) and thematic analysis (38.8\%) stood out as the most common data analysis procedures. 
Table 1 - Characterization of the researches analyzed. Rio Grande do Norte, Brazil, 2019

\section{Variable}

n

$\%$

\section{Type of study}

Scientific article

110

90.9

Thesis

7

5.8

Dissertation

4

Year of publication

$2003-2008$

$2009-2013$

24

$2014-2018$

89

73.5

\section{Author's field of knowledge}

Psychology

Medicine

Nursing

15

9

7

Social sciences*

6

4

Nutrition

Occupational therapy

Physical therapy

Computer science*

3

Odontology

Social work

Pedagogy*

1

1

1
25.6

12.4

7.4

5.8

5.0

0.8

0.8

0.8

0.8
Biomedicine

Source: Research Data, 2019

*Although the authors were not graduated in health field courses, the research developed by them fit within this field. 


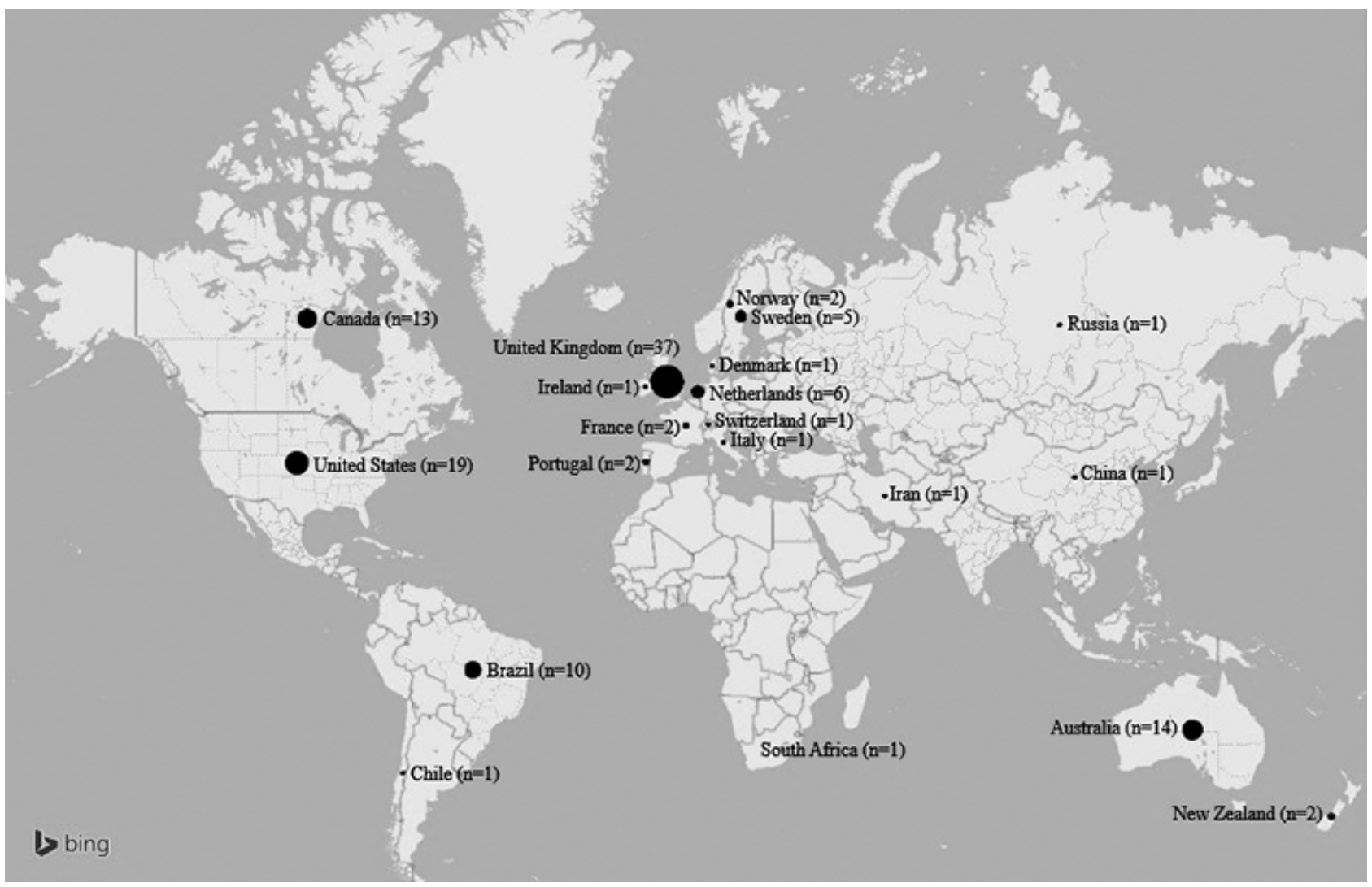

Figure 2 - Countries in which the researches analyzed were developed (in absolute numbers) Source: Research Data, 2019.

The other techniques used were data based theory (4.1\%); discourse analysis (2.5\%); phenomenological analysis (1.7\%); comparative analysis (0.8\%); and lexicographical analysis (0.8\%). The other researches (4.1\%) did not describe the analysis procedures they used.

It is relevant to highlight that some studies (21.5\%) used software to aid in the analysis of the qualitative data, which were: Nvivo (18.2\%); Atlas.ti (1.7\%); Dedoose (0.8\%); and CQPweb (0.8\%).

With regards to the participants of the researches, it is important to distinguish the studies that analyzed people (63.5\%) from those that analyzed posts (33.1\%), groups and sites (2.5\%), and videos (0.8\%).

Most investigations that analyzed people (38.0\%) carried out their data collection from online chats, forums and focus groups, with a mean of 57 subjects per group (a minimum of 5 and a maximum of 250 people). On the other hand, other researches (24.8\%) collected data from online questionnaires and e-mails, with a mean of 254 participants (a minimum of 4 and a maximum of 1740) subjects. One research did not state how many participants it had.

This work considered, as part of the group of investigations that analyzed posts, those that assessed posts, tweets, comments, and testimonies in websites and blogs. In these cases, the mean number of posts in the samples was 7267 posts (a minimum of 10 and a maximum of 228130).

The chart also includes the benefits and limitations reported by the authors with regards to the use of online data collection strategies for qualitative researches (Chart 1).

In general, the benefits involve the possibility of accessing large samples, with people from different places, in addition to the fact that the investigation process is neutral, since there is no involvement between the researcher and the subjects being researched. Regarding limitations, a possible selection bias stands out, since in these studies only the data of people with Internet access is collected. 


\begin{tabular}{|c|c|c|}
\hline $\begin{array}{l}\text { Online data collection } \\
\text { strategies (\%) }\end{array}$ & Benefits & Limitations \\
\hline $\begin{array}{l}\text { Online questionnaires } \\
\qquad(27.3 \%)\end{array}$ & $\begin{array}{l}\text { Access to large samples } \\
\text { Wide geographical coverage } \\
\text { Low cost } \\
\text { Data collection neutrality } \\
\text { Possibility of anonymity } \\
\text { Time to ponder on the matter }\end{array}$ & $\begin{array}{l}\text { High rate of unanswered questions } \\
\text { Impossibility of clarifying or debating } \\
\text { the answers } \\
\text { Superficial responses } \\
\text { Selection bias }\end{array}$ \\
\hline $\begin{array}{l}\text { Online forums } \\
\qquad(27.3 \%)\end{array}$ & $\begin{array}{l}\text { Access to large samples } \\
\text { Wide geographical coverage } \\
\text { Collection was enriched by the interaction } \\
\text { between subjects } \\
\text { Data collection neutrality } \\
\text { It was possible to collect data on } \\
\text { sensitive subjects }\end{array}$ & $\begin{array}{l}\text { It was impossible to collect } \\
\text { sociodemographic data } \\
\text { Superficial responses } \\
\text { There was a chance of } \\
\text { communication noise } \\
\text { Selection bias }\end{array}$ \\
\hline $\begin{array}{l}\text { Facebook } \\
(14.9 \%)\end{array}$ & $\begin{array}{l}\text { Access to large samples } \\
\text { Wide geographical coverage } \\
\text { Data collection with teenagers } \\
\text { Low cost } \\
\text { Data collection neutrality } \\
\text { Relative anonymity }\end{array}$ & $\begin{array}{l}\text { It was difficult to collect } \\
\text { sociodemographic data } \\
\text { It was impossible to access certain data } \\
\text { due to privacy settings } \\
\text { Selection bias }\end{array}$ \\
\hline $\begin{array}{l}\text { Websites } \\
\text { (9.9\%) }\end{array}$ & $\begin{array}{l}\text { Access to large samples } \\
\text { Low cost } \\
\text { Data collection neutrality }\end{array}$ & $\begin{array}{l}\text { It was impossible to collect } \\
\text { sociodemographic data } \\
\text { Selection bias }\end{array}$ \\
\hline $\begin{array}{l}\text { Blogs } \\
(9.1 \%)\end{array}$ & $\begin{array}{l}\text { Access to large samples } \\
\text { Anonymity } \\
\text { Low cost } \\
\text { Data collection neutrality } \\
\text { It was possible to collect data on } \\
\text { sensitive subjects }\end{array}$ & $\begin{array}{l}\text { It was impossible to collect } \\
\text { sociodemographic data } \\
\text { Impossibility of clarifying or debating } \\
\text { the answers } \\
\text { Possibility of losing data } \\
\text { Selection bias }\end{array}$ \\
\hline $\begin{array}{l}\text { E-mail } \\
(8.3 \%)\end{array}$ & $\begin{array}{l}\text { Access to large samples } \\
\text { Wide geographical coverage } \\
\text { It was possible to collect data on } \\
\text { sensitive subjects } \\
\text { Time to ponder on the matter }\end{array}$ & $\begin{array}{l}\text { High rate of unanswered questions } \\
\text { Responses took a long time } \\
\text { Responses were not spontaneous } \\
\text { Superficial responses }\end{array}$ \\
\hline $\begin{array}{l}\text { Online focus groups } \\
\qquad(5.8 \%)\end{array}$ & $\begin{array}{l}\text { Wide geographical coverage } \\
\text { Secure storage of data } \\
\text { Low cost } \\
\text { The group influence effect was minimized } \\
\text { Possibility of anonymity }\end{array}$ & $\begin{array}{l}\text { Non-verbal data was impossible to collect } \\
\text { Superficial responses }\end{array}$ \\
\hline $\begin{array}{l}\text { Twitter } \\
(4.1 \%)\end{array}$ & $\begin{array}{l}\text { Access to large samples } \\
\text { It was possible to map the opinions of } \\
\text { the subjects }\end{array}$ & $\begin{array}{l}\text { Ethical aspects } \\
\text { Superficiality (character limit) }\end{array}$ \\
\hline
\end{tabular}

Chart 1 - Benefits and difficulties in the use of online data collection strategies in qualitative researches 


\begin{tabular}{|c|l|l|}
$\begin{array}{c}\text { Online data collection } \\
\text { strategies (\%) }\end{array}$ & \multicolumn{1}{|c|}{ Benefits } & \multicolumn{1}{c|}{ Limitations } \\
\hline Chat & $\begin{array}{l}\text { Wide geographical coverage } \\
\text { Secure storage of data } \\
\text { Data collection with teenagers }(2.5 \%) \\
\text { Low cost } \\
\text { It was possible to collect data on } \\
\text { sensitive subjects }\end{array}$ & $\begin{array}{l}\text { Slower data collection } \\
\text { Superficial responses } \\
\text { Selection bias }\end{array}$ \\
\hline YouTube & $\begin{array}{l}\text { Access to large samples } \\
\text { Access to large volumes of data }\end{array}$ & Selection bias \\
\hline
\end{tabular}

Chart 1 - Cont.

Source: Research data, 2019

\section{DISCUSSION}

The predominance of studies classified as white literature (scientific articles) is a positive aspect, since these are documents that are easy to find, disseminate, and obtain. They also result from professional production/edition mechanisms, meaning they are highly visible ${ }^{(6)}$. Research published about these resources will, as a result, offer easier access to other researchers, optimizing their use - a fundamental feature of investigations that take advantage of innovative data collection methods.

The publications, which have been trending upwards through the years (especially in the last five), come from 20 different countries and have been carried out by qualitative researchers from 15 different fields of knowledge. That shows that there is a willingness to innovate in qualitative researches which are growing, contemporary, and multidisciplinary. That is in accordance to the perception that being proficient in the use of new investigation techniques is one of the key elements of reaching new standards with regards to research ${ }^{(7)}$.

The use of non-conventional data collection methods involves creativity, planning, and proficient use of technique. As a result, the research is methodologically sound, which is paramount for the production of consistent, reliable, and replicable data ${ }^{(8)}$.

In this landscape, the Internet is increasingly seen as valuable tool to collect information, through the use of its navigation and interaction resources ${ }^{(9)}$. In general, quantitative data collection on the Internet is well documented, especially using electronic forms. However, the discussion of how well it can generate qualitative data is still incipient, despite the growing trend that can be seen in this scoping review.

Internet-based qualitative researchers have generally been ethnographic, using participative methods $s^{(9)}$. This strategy was called "nethnography" by its authors ${ }^{(10-15)}$.
This is an emerging qualitative data collection method, which makes it possible for researchers to obtain a natural and immersive view about online interactions ${ }^{(10)}$. The nethnographic approach makes it possible for a broad set of opinions to be gathered, demands significantly less resources than in-person interviews or focus groups, and substantially diminishes the influence of the researcher in the results, since there are no researchers present when the comments and/ or testimonies are published ${ }^{(4,10)}$. This strategy was especially common in researches that used forums and blogs as data collection environments.

Regarding the approach of the researches evaluated, only $11.6 \%$ used a mixed data analysis approach ${ }^{(16-29)}$. The others were exclusively qualitative. This is not a problem in itself, but shows that the use of mixed approaches in researches in the health field is still incipient ${ }^{(30)}$.

Mixed approaches are understood in many ways, even receiving many names - mixed methods and combined methods, for instance -, and consist in the use of quantitative and qualitative strategies in the same research project. That is justified when the phenomenon being analyzed is complex and broad(3).

However, it should be highlighted that the choice of a mixed data analysis approach must have solid scientific bases, so that both the quantitative and qualitative aspects of a research can offer essential information to contribute in the understanding of the phenomenon investigated. This strategy was not used very frequently in this study.

Although this combination of data analysis approaches was not used often, a significant number of researches used a combination of data collection techniques, sometimes mixing online and in-person ones ${ }^{(9,2,31-37)}$. Using data from different techniques complementarily was highlighted by researchers as a way to enrich analyses ${ }^{(9)}$. This strategy, called method triangulation by some investigators, stems from the 
understanding that the adoption of multiple methods can show multiple facets of a research ${ }^{(38)}$.

In this context, the complexity of the modern world and, therefore, of its objects of study, demands strategies (both for data collection and analysis) that are complex and capable of dealing with the multiple points of view and perspectives of a phenomenon that can be considered in a variety of ways, and oftentimes cannot be seen as a whole from one single vantage point ${ }^{(39)}$.

The preoccupation with analyses that are methodologically sound concerning scientific interpretation and the complexity of the data analyzed can also be seen in the explanations presented by the researches evaluated about their own data analysis procedures.

On one hand, content analysis stood out as a theoretical reference for the studies ${ }^{(12-13,15-19,22,27,31-34,37,40-82)}$. This is an internationally recognized method, disseminated by Laurence Bardin through his work L'analyse de contenu, which shows, systematizes and express the content of messages, aiming at logically deducing the data analyzed ${ }^{(83)}$.

On the other hand, a large group of investigations used Computer-Assisted Qualitative Data Analysis Software (CAQDAS) to aid in data analysis ${ }^{(9-10,18-19,22,32,36,42,45-46,50-}$ $51,53,55,57,61,63,65,72,78-79,84-88)$. This shows an interest to innovate research methods to deal with current demands due to the methodological care of qualitative investigations and to the creativity of the researcher. The use of these software also offers benefits, especially the optimization of data organization, diminishing the time it takes to code large blocks of text. It also aids in the performance of different types of analyses ${ }^{(89)}$.

With regards to the samples of the investigations (subjects, posts, or others), they were in accordance to the benefits explained by each online data collection strategy being used.

Studies that used chat rooms, forums, and online focus groups had smaller samples with subjects, and stated that this strategy has an unique advantage as it allows sensitive subjects to be investigated, including those that deal with private issues which, often, are difficult to evaluate in person ${ }^{(87)}$.

On the other hand, researches that collected data from online questionnaires, e-mails, or posts, had samples with a very high number of subjects or posts, indicating as their main benefit the possibility of accessing large samples, with broad geographic coverage( ${ }^{(7,90)}$.

Ten different online data collection strategies were used in the researches analyzed, including: asynchronous tools (online questionnaires, online forums, websites, blogs, e-mail and YouTube); synchronous resources (online focus groups and chat rooms); and social networks (Facebook and Twitter).
Concerning the benefits of online data collection strategies, some stood out: the possibility of accessing large samples from different places; the low cost, when compared to in-person techniques, both for the researcher and for the subjects; the neutrality of the research process, which increases the internal reliability of the study, since it is possible to collect the data with no potential influence from the researcher ${ }^{(46)}$.

As to their limitations, potential selection biases were common, since participation in the study is restricted to subjects with Internet access, and even, depending on the online data strategy used, to those who habitually use certain online tools (forums, social networks, Facebook, etc.)(10).

The superficiality of responses and the impossibility of accessing demographic data from the subjects were also limitations reported by researches that used different online data collection techniques ${ }^{(43)}$.

It is important to highlight the limits and benefits of synchronous and asynchronous online data collection strategies. The synchronous strategy had as its main benefit the possibility of interacting with subjects from different places and the diminution of the group influence effect, which generally occurs when group data is collected in-person ${ }^{(91)}$.

On the other hand, the slow and superficial responses found in this type of online data collection was pointed out as limitations. Researchers ${ }^{(9)}$ reported that the online interviews through chat rooms took twice as long as in-person ones and produced much less words: a 120 minutes online interview produced nearly seven pages of text, while an in-person 90 minutes long interview produced from 30 to 40 pages of text. It was also found that the exchange of answers and responses was clearly influenced by the reading, typing, and reflecting abilities of the respondents.

Concerning asynchronous online data collection strategies, the main benefit mentioned was the time afforded the participants to consider their responses. On the other hand, the impossibility of debating, the lack of spontaneity of the answers, and the high rate of participants who did not answer were reported as limitations ${ }^{(36)}$.

The importance of the planning stage of qualitative researches stands out. The researcher should guide the investigation using coherent and adequate theoretical references, and it is paramount that they have a detailed knowledge on the data collection process used for the research.

Online data collection strategies, as a result, are a fertile ground for qualitative researches, in accordance to this era in which technology is increasingly a part of people's lives. Qualitative investigators, therefore, must use them creatively and with methodological care. 


\section{CONCLUSIONS}

This study analyzed 121 researches published from 2003 to 2018, from 20 countries and 15 fields of knowledge. Ten different online data collection tools were used: online questionnaires, online forums, Facebook, websites, blogs, e-mail, online focus groups, Twitter, chat rooms, and YouTube.

The researches highlighted, as benefits of the use of these strategies, the possibility of accessing large samples, the large geographical coverage, and the neutrality of the research process. As to their limitations, a possible selection bias stands out, since in these studies only the data of people with Internet access is collected.

As a limitation of this study, the quality of the abstracts analyzed in the first stage of the scoping review should be mentioned, since it could have led certain researches to not be selected due to the absence of descriptions of methodological procedures. It also stands out that the results presented must be understood within the context of the databases used and of the time period in which data collection was carried out.

This study hopes to contribute to the discussion about the theme through the mapping of the online data collection strategies that have been used in qualitative investigations in the field of health and represent new possibilities for qualitative researchers.

These findings may subsidize qualitative researches that aim to use the strategies identified to contribute for the construction of innovative knowledge in the field of health and in Nursing. This could lead to improvements in the teaching of scientific methodologies that incorporates this knowledge; the production of knew researches based on online strategies; and the practice of healthcare, which can benefit from the findings of said investigations.

\section{REFERENCES}

1. Mercado LPL. Pesquisa qualitativa on-line utilizando a etnografia digital. Rev Teias. 2012 [cited 2019 Jul 15];13(30):169-83. Available from: https://www.epublicacoes.uerj.br/index.php/revistateias/article/view/24276/17255

2. Mendes CM. A pesquisa online: potencialidades da pesquisa qualitativa no ambiente virtual. Hipertextus. 2009 [cited 2019 Jul 15];2:1-9. Available from: http://www.hipertextus.net/volume2/Conrado-Moreira-MENDES.pdf

3. Feitosa LRC, Araújo, CMM. Pesquisas qualitativas em contexto da web: etnografia em debate. In: $3^{\circ}$ Congresso Ibero-Americano em Investigação Qualitativa: Atas CIAQ2014:; 2014 jul 14-16. Badajoz, Espanha. Badajoz: Universidad de Extremadura, 2014 [cited 2019 Jul 15]. v.3: Investigação Qualitativa em Ciências Sociais, p.384-5. Available from: https://proceedings.ciaiq.org/index. php/CIAIQ/article/view/505/500
4. Fernandes $L S$, Calado C, Araujo CAS. Social networks and health practices: influence of a diabetes online community on adherence to treatment. Ciênc Saúde Coletiva. 2018;23(10):3357-68. doi: https://doi.org/10. 1590/1413-812320182310.14122018

5. Joanna Briggs Institute (AU). The Joanna Briggs Institute Reviewers' Manual 2015: Methodology for JBI Scoping Reviews. Adelaide: JBI; 2015 [cited 2019 ul 15]. Available from: https://nursing.lsuhsc.edu/JBI/docs/ReviewersManuals/ Scoping-.pdf

6. Botelho RG, Oliveira CC. Literaturas branca e cinzenta: uma revisão conceitual. Cienc Informação. 2015 [cited 2019 Jul 15];44(3):501-13. Available from: http://revista.ibict.br/ciinf/article/view/1804/3251

7. Erdmann AL. The need to achieve excellence in nursing research [editorial]. Acta Paul Enferm. 2009;22(2):v-vi. doi: https://doi.org/10.1590/S0103-2100 2009000200001

8. Medeiros M. Thinking about qualitative research [editorial]. Rev Eletr Enf. 2012;14(2):226-7. doi: https://doi.org/10.5216/ree.v14i2.13628

9. Davis M, Bolding G, Hart G, Sherr L, Elford J. Reflecting on the experience of interviewing online: perspectives from the Internet and HIV study in London. AIDS Care. 2004;16(8):944-52. doi: https://doi.org/10.1080/09540120412331292499

10. Gisles EL, Holmes M, McColl E, Sniehotta FF, Adams JM. Acceptability of financial incentives for breastfeeding: thematic analysis of readers' comments to UK online news reports. BMC Pregnancy and Childbirth. 2015;15:116. doi: https://doi.org/10.1186/s12884-015-0549-5

11. Elvey R, Voorhees J, Bailey S, Burns T, Hodgson D. GPs' views of health policy changes: a qualitative 'netnography' study of UK general practice online magazine commentary. Br J Gen Pract. 2018;68(671):441-8. doi: https://doi. org/10.3399/bjgp 18X696161

12. Santos SM. Megaeventos esportivos, educação física e convergência digital: consumo, circulaçãoe produção por professores em formaçãoinicial [dissertação]. Florianópolis (SC): Programa de Pós-graduação em Educação Física, Universidade Federal de Santa Catarina; 2014 [cited 2019 Jul 15]. Available from: https:// repositorio.ufsc.br/handle/123456789/123257

13. Isupova OG. Support through patient internet-communities: lived experience of Russian in vitro fertilization patients. Int I Qual Stud Health Well-being. 2011;6(3):5907. doi: https://doi.org/10.3402/qhw.v6i3.5907

14. Barros OC, Serpa Júnior OD. Ouvir vozes: um estudo netnográico de ambientes virtuais para ajuda mútua. Physis. 2017;27(4):867-88. doi: https://doi. org/10.1590/s0103-73312017000400002

15. Fernandes LS, Calado C, Araujo CAS. Social networks and health practices: influence of a diabetes online community on adherence to treatment. Cienc Saude Coletiva. 2018;23(10):3357-68. doi: https://doi.org/10.1590/ 1413-812320182310.14122018

16. Eng JJ, Noonan VK, Townson AF, Higgins CE, Rogers J, Wolfe DL. Impact of an online medical internet site on knowledge and practice of health care providers: a mixed methods study of the Spinal Cord Injury Rehabilitation Evidence Project. J Med Internet Res. 2014;16(12):e296. doi: https://doi.org/10.2196/jmir.3453

17. Dickinson KM, Watson MS, Prichard I. Are clean eating blogs a source of healthy recipes? A comparative study of the nutrient composition of foods with and without clean eating claims. Nutrients. 2018;10(10):1440. doi: https://doi. org/10.3390/nu10101440

18. White BK, Giglia RC, Scott JA, Burns SK. How new and expecting fathers engage with an app-based online forum: qualitative analysis. JMIR Mhealth Uhealth. 2018;6(6):e144. doi: https://doi.org/10.2196/mhealth.9999 
19. Farmer J, Bigby C, Davis H, Carlisle K, Kenny AJ, Huysmans RD. The state of health services partnering with consumers: evidence from an online survey of Australian health services. BMC Health Serv Res. 2018;18(1):628. doi: https:// doi.org/10.1186/s12913-018-3433-y

20. Sukthankar R. A portfolio of academic, therapeutic practice and research work including an investigation of :"What is not said", practitioners' experience of the loss of visual and verbal clues in the online therapeutic relationship : an interpretative phenomenological analysis [thesis]. Guildford, England: Faculty of Health and Medical Sciences, University of Surrey; 2017.

21. McConnell E, Néray B, Hogan B, Korpak A, Clifford A, Birkett M. "Everybody Puts Their Whole Life on Facebook": identity management and the online social networks of LGBTQ Youth. Int J Environ Res Public Health. 2018;15(6):e1078. doi: https://doi.org/10.3390/ijerph15061078

22. Tustin JL, Crowcroft NS, Gesink D, Johnson I, Keelan J, Lachapelle B. Userdriven comments on a facebook advertisement recruiting canadian parents in a study on immunization: content analysis. JMIR Public Health Surveill. 2018;4(3):e10090. doi: https://doi.org/10.2196/10090

23. Burrows T, Hutchesson M, Chai LK, Rollo M, Skinner G, Collins C. Nutrition interventions for prevention and management of childhood obesity: what do parents want from an eHealth program? Nutrients. 2015;7(12):10469-79. doi: https://doi.org/10.3390/nu7125546

24. Bright P, Hambly K. Patients using an online forum for reporting progress when engaging with a six-week exercise program for knee conditioning: feasibility study. JMIR Rehabil Assist Technol. 2018;5(1):e9. doi: https://doi.org/10.2196/ rehab.8567

25. Wray J, Brown K, Tregay J, Crowe S, Knowles R, Bull K, et al. Parents'experiences of caring for their child at the time of discharge after cardiac surgery and during the postdischarge period: qualitative study using an online forum. J Med Internet Res. 2018;20(5):e155. doi: https://doi.org/10.2196/jmir.9104

26. Hunt J. An initial study of transgender people's experiences of seeking and receiving counselling or psychotherapy in the UK. Couns Psychother Res. 2014;14(4):288-96. doi: https://doi.org/10.1080/14733145.2013.838597

27. Stuart B, Rumsby K, Santer M, Ridd MJ, Francis NA, Chorozoglou M, et al. Feasibility of weekly participant-reported data collection in a pragmatic randomised controlled trial in primary care: experiences from the BATHE trial (Bath Additives for the Treatment of cHildhood Eczema). Trials. 2018;19:582. doi: https://doi.org/10.1186/s13063-018-2962-3

28. Dennehy C. Clinical decision-making regarding communication book use by people with aphasia: a survey of speech and language therapists in Ireland [thesis]. Limerick, Ireland: Department of Clinical Therapies, University of Limerick; 2013.

29. Kennedy AJ, Brumby SA, Versace VL, Brumby-Rendell T. Online assessment of suicide stigma, literacy and effect in Australia's rural farming community. BMC Public Health. 2018;18:846. doi: https://doi.org/10.1186/s12889-018-5750-9

30. Guerrero-Castañeda RF, Prado ML, Ojeda-Vargas MG. Epistemological critical reflection on nursing research mixed methods. Enferm Universitaria. 2016;13(4):256-52. doi: https://doi.org/10.1016/j.reu.2016.09.001

31. Terp M, Jørgensen R, Laursen BS, Mainz J, Bjørnes CD. A smartphone app to foster power in the everyday management of living with schizophrenia: qualitative analysis of young adults' perspectives. JMIR Ment Health. 2018;5(4):e10157. doi: https://doi.org/10.2196/10157

32. Jamison J, Sutton S, Mant J, De Simoni A. Online stroke forum as source of data for qualitative research: insights from a comparison with patients' interviews. BMJ Open. 2018;8:e020133. doi: https://doi.org/10.1136/bmjopen-2017-020133
33. Peters LW, Nawijn L, van Kesteren NM. How adolescents with diabetes experience social support from friends: two qualitative studies. Scientifica (Cairo). 2014;2014:415849. doi: https://doi.org/10.1155/2014/415849

34. Poliziani M, Koch M, Liu X. Striving for more good days: patient perspectives on botulinum toxin for the treatment of cervical dystonia. Patient Prefer Adherence. 2016;10:1601-8. doi: https://doi.org/10.2147/PPA.S106560

35. Brighton LJ, Pask S, Benalia H, Bailey S, Sumerfield M, Witt J, et al. Taking patient and public involvement online: qualitative evaluation of an online forum for palliative care and rehabilitation research. Res Involv Engagem. 2018;4:14. doi: https://doi.org/10.1186/s40900-018-0097-z

36. Dowling S, Brown A. Exploring the experiences of women who breastfeed long-term. Breastfeed Med. 2013;8(1):45-52. doi: https://doi.org/10.1089/ bfm.2012.0057

37. Irani MD, Abdoli S, Bijan I, Parvizy S, Fatemi NS, Amini M. Strategies to overcome type 1 diabetes-related social stigma in the Iranian society. Iran J Nurs Midwifery Res. 2014 [cited 2019 Jul 20];19(5):456-63. Available from: https:// www.ncbi.nlm.nih.gov/pmc/articles/PMC4223961/

38. Tuzzo AS, Braga CFO. 0 processo de triangulação da pesquisa qualitativa: o metafenômeno como gênese. Rev Pesq Qualitat. 2016 [citado 2019 jul 15];4(5):140-58. Disponível em: https://editora.sepq.org.br/index.php/rpq/ article/view/38/31

39. Tuzzo SA. Os sentidos do impresso. Goiânia: Gráfica UFG; 2016.

40. Hayward L. Integrating Web-enhanced instruction into a research methods course: examination of student experiences and perceived learning. J Phys Therapy Educ. 2004;18(2):54-63. doi: https://doi.org/10.1097/00001416200407000-00008

41. Rochat N, Hauw D, Antonini Philippe R, Crettaz von Roten F, Seifert L. Comparison of vitality states of finishers and withdrawers in trail running: an enactive and phenomenological perspective. PLoS One. 2017;12(3):e0173667. doi: https:// doi.org/10.1371/journal.pone.0173667

42. McDonagh JE, Shaw KL, Prescott J, Smith FJ, Roberts R, Gray NJ. "Sometimes I feel like a pharmacist": identity and medication use among adolescents with juvenile arthritis. Pediatr Rheumatol Online J. 2016;14(57). doi: https://doi. org/10.1186/s12969-016-0117-1

43. Zanchetta MS, Cognet M, Lam-Kin-Teng MR, Dumitriu ME, Renaud L, Rhnaume J. From early detection to rehabilitation in the community: reading beyond the blog testimonies of survivors' quality of life and prostate cancer representation. Health Qual Life Outcomes. 2016;14:171. doi: https://doi.org/10.1186/ s12955-016-0568-6

44. Cunha JHS. Os significados da morte para os profissionais de saúde frente ao cuidado à pessoa com câncer [dissertação]. Uberaba (MG): Programa de PósGraduação stricto sensu em Atenção à Saúde, Universidade Federal do Triângulo Mineiro; 2017.

45. Bezreh T, Laws MB, Taubin T, Rifkin DE, Wilson IB. Challenges to physicianpatient communication about medication use: a window into the skeptical patient's world. Patient Prefer Adherence. 2012;6:11-8. doi: https://doi. org/10.2147/PPA.S25971

46. Carlsson T, Landqvist M, Mattsson E. Communication of support and critique in Swedish virtual community threads about prenatal diagnoses of fetal anomalies. BMC Pregnancy Childbirth. 2016;16:199. doi: https://doi.org/10.1186/s12884016-0989-6

47. Tanaka R, Banerjee A, Surikova J, Tracey J, Payne A, Ross H, et al. A moderated e-forum for adults with cardiovascular disease: usability study. JMIR Hum Factors. 2018:5(2):e20. doi: https://doi.org/10.2196/humanfactors.8820 
48. Pitman A, De SouzaT, Khrisna Putri A, Stevenson F, King M, Osborn D, etal. Support needs and experiences of people bereaved by suicide: qualitative findings from a cross-sectional British study of bereaved young adults. Int J Environ Res Public Health. 2018;15(4):666. doi: https://doi.org/10.3390/ijerph15040666

49. Meier A, Lyons EJ, Frydman G, Forlenza M, Rimer BK. How cancer survivors provide support on cancer-related Internet mailing lists. J Med Internet Res. 2007;9(2):e12. doi: https://doi.org/10.2196/jmir.9.2.e12

50. Kallem S, Gruver RS, Virudachalam S, Fiks AG. Mothers' Facebook posts about infant health: findings from the Grow2Gether study. BMC Pediatr. 2018;18:341. doi: https://doi.org/10.1186/s12887-018-1315-4

51. César F, Costa P, Oliveira A, Fontaine AM. “To Suffer in Paradise": Feelings mothers share on Portuguese Facebook sites. Front Psychol. 2018;9:1797. doi: https:// doi.org/10.3389/fpsyg.2018.01797

52. Bender JL, Jimenez-Marroquin MC, Jadad AR. Seeking support on facebook: a content analysis of breast cancer groups. J Med Internet Res. 2011;13:e16. doi: https://doi.org/10.2196/jmir.1560

53. Skelton K, Evans R, LaChenaye J, Amsbary J, Wingate M, Talbott L. Utilization of online focus groups to include mothers: a use-case design, reflection, and recommendations. Digit Health. 2018:4:2055207618777675. doi: https://doi. org/10.1177/2055207618777675

54. Farrell A. Accuracy of online discussion forums on common childhood ailments. J Med Libr Assoc. 2018;106(4):455-63. doi: https://doi.org/10.5195/ jmla.2018.355

55. Bergene EH, Rø TB, Steinsbekk A. Strategies parents use to give children oral medicine: a qualitative study of online discussion forums. Scand J Prim Health Care. 2017;35(2):221-8. doi: https://doi.org/10.1080/02813432.2017.1333308

56. Rennó Junqueira C, Tavares da Silva PM, Rennó Junqueira S, Ramos DLP. 0 ensino de bioética: avaliação discente por meio de fóruns de discussão na Internet. Acta Bioeth. 2012;18(1):93-100. doi: https://doi.org/10.4067/ S1726-569X2012000100008

57. Libreri C. Online patients knowledge sharing: the role of web peer exchanges in the diabetes care [thesis]. Milan, Italy: Universita' Cattolica Del Sacro Cuore; 2012 [cited 2019 Jul 20]. Available from: https://core.ac.uk/download/ pdf/60782444.pdf

58. Martin Salzmann-Erikson RN, Henrik Eriksson RN. Torrenting values, feelings, and thoughts-Cyber nursing and virtual self-care in a breast augmentation forum. Int J Qual Stud Health Well-being. 2011;6(4):7378 doi: https://doi. org/10.3402/qhw.v6i4.7378

59. Nilsson J, Jervaeus A, Lampic C, Eriksson LE, Widmark C, Armuand GM, et al. 'Will I be able to have a baby?' results from online focus group discussions with childhood cancer survivors in Sweden. Hum Reprod. 2014;29(12):2704-11. doi: https://doi.org/10.1093/humrep/deu280

60. Koper I, Pasman HRW, Onwuteaka-Philipsen BD. Experiences of Dutch general practitioners and district nurses with involving care services and facilities in palliative care: a mixed methods study. BMC Health Serv Res. 2018;18(1):841. doi: https://doi.org/10.1186/s12913-018-3644-2

61. Kamudoni P, Mueller B, Halford J, Schouveller A, Stacey B, Salek MS. The impact of hyperhidrosis on patients' daily life and quality of life: a qualitative investigation. Health Qual Life Outcomes. 2017;15(1):121. doi: https://doi. org/10.1186/s12955-017-0693-X

62. Rolls K, Hansen M, Jackson D, Elliott D. Why we belong - exploring membership of healthcare professionals in an intensive care virtual community via online focus groups: rationale and protocol. JMIR Res Protoc. 2016;5(2):e99. doi: https://doi.org/10.2196/resprot.5323
63. Raggatt M, Wright CJC, Carrotte E, Jenkinson R, Mulgrew K, Prichard I, et al. "I aspire to look and feel healthy like the posts convey": engagement with fitness inspiration on social media and perceptions of its influence on health and wellbeing. BMC Public Health. 2018;18(1):1002. doi: https://doi.org/10.1186/ s12889-018-5930-7

64. Furness PJ, Vogt K, Ashe S, Taylor S, Haywood-Small S, Lawson K. What causes fibromyalgia? an online survey of patient perspectives. Health Psychol Open. 2018;5(2):2055102918802683. doi: https://doi.org/10.1177/205510291880 2683

65. Farías L, López C. La formación de pregrado de terapia ocupacional en Chile visto desde la perspectiva de los estudiantes: ¿cuál es la percepción de necesidades que tienen los estudiantes de terapia ocupacional en relación a su proceso de formación?. Rev Chil Ter Ocup. 2013;13(1):43-50. doi: https://doi. org/10.5354/0719-5346.2013.27451

66. Gibson, K., Cartwright, C. \& Read, J.'In my life antidepressants have been. ..': a qualitative analysis of users' diverse experiences with antidepressants. BMC Psychiatry. 2016;16:135. doi: https://doi.org/10.1186/s12888-016-0844-3

67. Curtis R, Robertson P, Forst A, Bradford C. Postpartum mood disorders: results of an online survey, Couns Psychother Res. 2007;7(4):203-10. doi: https://doi. org/10.1080/14733140701706060

68. Cavalcante RB, Kerr-Pinheiro MM, Guimarães EAA, Miranda RM. Panorama de definição e implementação da Política Nacional de Informação e Informática em Saúde. Cad Saúde Pública. 2015;31(5):960-70. doi: https://doi. org/10.1590/0102-311X00095014

69. Galvão EA, Sousa MF. As escolas técnicas do SUS: que projetos políticopedagógicos as sustentam? Physis. 2012;22(3):1159-89. doi: https://doi. org/10.1590/S0103-73312012000300017

70. Bengtsson M, Carlson E. Knowledge and skills needed to improve as preceptor: development of a continuous professional development course - a qualitative study part I. BMC Nurs. 2015;14:51. doi: https://doi.org/10.1186/s12912015-0103-9

71. Prazeres F, Santiago L. The knowledge, awareness, and practices of Portuguese general practitioners regarding multimorbidity and its management: qualitative perspectives from open-ended. Int J Environ Res Public Health. 2016;13(11):e1097. doi: https://doi.org/10.3390/ijerph13111097

72. Jones K, Ewens $A$. Achieving excellence in postgraduate community nurse practice placements. Br J Community Nurs. 2010;15(12):604-10. doi: https:// doi.org/10.12968/bjcn.2010.15.12.604

73. Hawk C, Cambron J, Pahmeyer D. Issues in conducting research in chiropractic college clinics. J Manipulative Physiol Ther. 2008;31(4):301-7. doi: https://doi. org/10.1016/j.jmpt.2008.03.008

74. Gesser-Edelsburg A, Shalayeva S. Internet as a source of long-term and realtime professional, psychological, and nutritional treatment: a qualitative case study among former Israeli Soviet Union Immigrants. J Med Internet Res. 2017;19(2):e33. doi: https://doi.org/10.2196/jmir.7130

75. Brownlie J. Looking out for each other online: digital outreach, emotional surveillance and safe(r) spaces. Emotion, Space Soc. 2018;27:60-7. doi: https:// doi.org/10.1016/j.emospa.2018.02.001

76. Merolli M, Gray K, Martin-Sanchez F. Therapeutic affordances of social media: emergent themes from a global online survey of people with chronic pain. J Med Internet Res. 2014;16(12):e284. doi: https://doi.org/10.2196/jmir.3494

77. Vilhelmsson A, Svensson T, Meeuwisse A. A Pill for the ill? patients' reports of their experience of the medical encounter in the treatment of depression. PLOS One. 2013;8(6):e66338. doi: https://doi.org/10.1371/journal.pone.0066338 
78. Ahlström BH, WentzE. Difficulties in everyday life: young persons with attentiondeficit/hyperactivity disorder and autism spectrum disorders perspectives: a chat-log analysis. Int I Qual Stud Health Well-being. 2014;9:23376. doi: https:// doi.org/10.3402/qhw.v9.23376

79. Henrich N, Holmes B. What the public was saying about the H1N1 vaccine: perceptions and issues discussed in on-line comments during the 2009 H1N1 pandemic. PLoS One. 2011;6(4):e18479. doi: https://doi.org/10.1371/journal. pone.0018479

80. Chan B, Lopez A, Sarkar U. The canary in the coal mine tweets: social media reveals public perceptions of non-medical use of opioids. PLOS One. 2015;10(8):e0135072. doi: https://doi.org/10.1371/journal.pone.0135072

81. Taylor J, Pagliari C. \#Deathbedlive: the end-of-life trajectory, reflected in a cancer patient's tweets. BMC Palliat Care. 2018;17:17. doi: https://doi.org/10.1186/ s12904-018-0273-9

82. Gao X, Hamzah SH, Yiu CK, McGrath C, King NM. Dental fear and anxiety in children and adolescents: qualitative study using YouTube. J Med Internet Res. 2013;15(2):e29. doi: https://doi.org/10.2196/jmir.2290

83. Silva AH, Cunha DE, Gaspary E, Moura GL, Figueira KK, Horbe TAN. Análise de conteúdo:fazemosoquedizemos?umlevantamentodeestudosquedizemadotara técnica. Conhec Interativo. 2017 [cited 2019 Jul 15];11(1):168-84. Availablefrom: http://app.fiepr.org.br/revistacientifica/index.php/conhecimentointerativo/ article/view/223/221

84. Prescott J, Gray NJ, Smith FJ, McDonagh JE. Blogging as a viable research methodology for young people with arthritis: a qualitative study. J Med Internet Res. 2015;17(3):e61. doi: https://doi.org/10.2196/jmir.3608
85. Poltawski L, Allison R, Briscoe S, Freeman J, Kilbride C, Neal D, et al. Assessing the impact of upper limb disability following stroke: a qualitative enquiry using internet-based personal accounts of stroke survivors. Disabil Rehabil. 2016;38(10):945-51. doi: https://doi.org/10.3109/09638288.2015.1068383

86. Lovatt M, Bath PA, Ellis J. Development of trust in an online breast cancer forum: a qualitative study. J Med Internet Res. 2017;19(5):e175. doi: https://doi. org/10.2196/jmir.7471

87. Chen AT, Kaplan SJ, Carriere R. A constant conversation: tuning into and harmonizing the needs and priorities of the body and mind. Int I Qual Stud Health Well-being. 2017;12(1):1350550. doi: https://doi.org/10.1080/174826 31.2017.1350550

88. Brookes $G$, Baker P. What does patient feedback reveal about the NHS? A mixed methods study of comments posted to the NHS Choices online service. BMJ Open. 2017;7:e013821. doi: https://doi.org/10.1136/bmjopen-2016-013821

89. Salvador P, Gomes A, Rodrigues C, Chiavone F, Alves K, Bezerril M, et al. Use of software in qualitative health research in Brazil: a scoping review. In: Costa AP, Reis LP, Souza FN, Moreira A, editors. ISQR 2017. Computer Supported Qualitative Research. Cham: Springer; 2018. p. 306-15 doi: https://doi. org/10.1007/978-3-319-61121-1

90. Godier LR, Park RJ. Does compulsive behavior in Anorexia Nervosa resemble an addiction? a qualitative investigation. Front Psychol. 2015;6(1608):1-12. Doi: https://doi.org/10.3389/fpsyg.2015.01608

91. King R, Bambling M, Lloyod C, Gomurra R, Smith S, Reid W et al. Online counselling: the motives and experiences of young people who choose the Internet instead of face to face or telephone counselling. J Counsell Psychother Res. 2007;6(3):169-74. doi: https://doi.org/10.1080/14733140600848179

\section{- Corresponding author:}

Pétala Tuani Candido de Oliveira Salvador petalatuani@hotmail.com

\section{Associate editor:}

Rosana Maffacciolli 